\title{
Improving City Health: How Can We Tell?
}

\author{
David Sharp
}

A recent study of 13 Spanish cities ${ }^{1}$ confirms excess mortality due to air pollution; air pollution increases the rate of primary care consultations in London ${ }^{2}$; and the World Health Organization (WHO) regional director for Europe claims that, in Europe, 100,000 premature deaths a year are attributable to air pollution. ${ }^{3}$ This pollution is largely generated by traffic and industry, so it is natural to assume that lowering of air pollution indices will be accompanied by reductions in registered mortality and measurable morbidity in urban populations. That prediction is testable. Unfortunately, health threats to cities are not just airborne ones; also, it is simplistic to describe urban living and working per se as dangerous. Within any city, there will be huge variations; there are parts of Greater London (and, no doubt, New York City) where life expectancy is above average for more socioeconomically deprived districts of those capitals. Nor is country life all bliss-witness the increased risk of rural suicide, lately confirmed by a US study. ${ }^{4}$ Proving that public health actions produce healthier people is far from easy.

WHO's Regional Office for Europe, which serves populations from the Azores to thousands of miles east in the Asian former Soviet Republic, has a Healthy Cities program (www.who.dk/healthy-cities). WHO defines a healthy city not as a city that is now healthy, with standard medical statistics to prove it, but as one that is health aware. The program is thus about "changing the ways in which cities think about, understand and make decisions about health," and such changes may prove to be an evidential challenge. A further complication is that "city" in WHO thinking is a generic term not restricted to western notions of cities or even the huge urban sprawls seen in some developing countries today. A "healthy city" may refer to a Pacific island or an Eastern European village, for example.

WHO's Healthy Cities covers nine broad areas:

- City health development planning

- Community participation

- Health impact assessments

- Poverty

- Social determinants of health

- Sustainable development

- Transport and health

- Urban governance

- Urban planning

In any project such as this, there will possibly be untestable initiatives and wellintentioned rhetoric; in the early days, that is understandable. As examples, we have had the fanfares accompanying the July 2002 launch of the Transport, Health, and Environment Pan-European Programme ${ }^{3}$ and the earlier, grand-sounding declarations on healthy European cities from gatherings in Milan (1990) and Athens 
(1998). Of course, WHO can only facilitate and encourage; it is does not pay for improved urban health services. This, too, makes it very difficult to judge how well the program is succeeding. A further complication is that tackling poverty-and it is poverty that lies behind so many urban health challenges-requires more political and economic power than is at the command of most city halls. British researchers evaluating Healthy Cities projects in the developing world ${ }^{5}$ noted lack of political commitment as a stumbling block. Reducing health disparities is an explicit focus of the ongoing Healthy Cities and Healthy People 2000 programs. In the city of Chicago, discouragingly, the latter program was unsuccessful. Indeed, the disparities got worse, but objective proof was at least sought. ${ }^{6}$

Phase 3 (1998-2002) of Europe's Healthy Cities ended in September of this year, and 2003 will see a European conference at which phase 3 results will be presented and the next phase launched. One can sympathize with the difficulties facing those in charge, but results, the success or failure of urban health initiatives of all sorts, will ultimately have to be presented and judged in terms the people that they are aimed at can understand. So far, it seems to be more the process, rather than the product, that is under the microscope.

\section{References}

1. Ballester F, Saez M, Perez-Hoyos S, et al. The EMECAM project: a multicentre study on air pollution and mortality in Spain: combined results for particulates and for sulfur dioxide. Occup Environ Med. 2002;59:300-308.

2. Hajat S, Anderson HR, Atkinson RW, Haines A. Effects of air pollution on general practice consultations for upper respiratory diseases in London. Occup Environ Med. 2002; 59:294-299.

3. World Health Organization/United Nations Economic Commission for Europe joint European press release EURO 13/02 (July 17, 2002). Launch of Transport, Health, and Environment Pan-European Programme. Copenhagen, Denmark: WHO Regional Office for Europe; 2002.

4. Singh GK, Siahpush M. Increasing rural-urban gradients in US suicide mortality, 19701997. Am J Public Health. 2002;92:1161-1167.

5. Harpham T, Burton S, Blue I. Healthy city projects in developing countries: the first evaluation. Health Promot Internation. 2001;16:111-125.

6. Silva A, Whitman S, Maragellos H, Ansell D. Evaluating Chicago's success in reaching the Healthy People 2000 goal of reducing health disparities. Public Health Rep. 2001; 116:484-494. 